\title{
INTERNATIONAL COOPERATION AND RESPONSIBILITY- SHARING TO PROTECT REFUGEES: WHAT, WHY AND HOW?
}

\author{
ReBecca Dowd* and Jane McAdam ${ }^{*}$
}

\begin{abstract}
While countries that receive refugees have certain legal obligations to assist and protect them, the legal duties of other States to step in and help relieve this burden is less clear. Despite multiple proposals, a mechanism to systematically, equitably and predictably allocate responsibilities between States at a global level has still not been agreed. The UN's High-Level Summit on Addressing Large Movements of Refugees on 19 September 2016 held some promise in this regard, but the resulting New York Declaration was more muted than earlier drafts. This article seeks to provide a unique insight into the meaning of responsibilitysharing and international cooperation from the perspective of individual States. It does so by examining statements they have made at various $\mathrm{UN}$ fora over the past decade. It focuses on the two main methods of sharing responsibilities, namely the provision of financial and other assistance to host countries, and the admission of refugees. It then considers the extent to which States perceive responsibility-sharing to be a legal obligation, as opposed to a voluntary undertaking, and analyses this in light of expert opinion. Finally, it discusses the principle of common but differentiated responsibilities, a concept drawn from international environmental law, and considers whether and how it might apply in the international refugee law context.
\end{abstract}

Keywords: burden-sharing, international cooperation, international protection, refugees, responsibility-sharing.

* BA, LLB/LP (Hons) (Flin), LLM (Essex); Refugee law research consultant. Rebecca previously worked for the United Nations High Commissioner for Refugees (UNHCR) for five years.

$\dagger$ BA (Hons), LLB (Hons) (Sydney), DPhil (Oxford); Scientia Professor and Director of the Andrew \& Renata Kaldor Centre for International Refugee Law, Faculty of Law, UNSW Sydney. This research was partially funded by the Research Council of Norway (Project No 235638). We thank Dr Madeline Garlick and the anonymous reviewers for their helpful comments. 
International cooperation and, in particular, cooperation among countries of origin or nationality, transit and destination, has never been more important; 'win-win' cooperation in this area has profound benefits for humanity. ${ }^{1}$

\section{INTRODUCTION}

'If there is one lesson to draw from the past few years', wrote the United Nations Secretary-General in mid-2016, 'it is that individual countries cannot solve [large-scale refugee movements] on their own. International cooperation and action ... must be strengthened.'2 The number of displaced people today is at an all-time high - 65.6 million in $2016^{3}$ - yet the distribution of refugees is starkly imbalanced with the vast majority hosted by low- and middle-income countries in developing regions. ${ }^{4}$

While countries that receive refugees have certain legal obligations to assist and protect them, the legal duties of other States to step in and help relieve this burden is less clear. ${ }^{5}$ Herein lies the dilemma: what can be done to more equitably distribute responsibility for refugee protection among States? This has been the subject of decades-long discussion and research by States, policymakers, academics, refugee law experts and the United Nations High Commissioner for Refugees (UNHCR). Yet, while multiple proposals have been put forward ${ }^{6}$ and individual States have made various overtures towards responsibility-sharing, ${ }^{7}$ a mechanism to systematically, equitably and

1 New York Declaration for Refugees and Migrants, UN Doc A/RES/71/1 (3 October 2016) para 11 .

2 In Safety and Dignity: Addressing Large Movements of Refugees and Migrants: Report of the Secretary-General, UN Doc A/70/59 (21 April 2016) para 3.

3 UNHCR, Global Trends: Forced Displacement in 2016 (19 June 2017) 2.

484 per cent of refugees were hosted in the developing world in 2016: ibid 2.

5 K Koser, 'Australia and the 1951 Refugee Convention' (Lowy Institute for International Policy, April 2016) 6; JC Hathaway and RA Neve, 'Making International Refugee Law Relevant Again: A Proposal for Collectivized and Solution-Oriented Protection' (1997) 10 HarvHumRtsJ 115,141 ; E Tendayi Achiume, 'Syria, Cost-Sharing, and the Responsibility to Protect Refugees' (2015) 100 MinnLRev 687, 690-1.

6 See, for example, PH Schuck, 'Refugee Burden-Sharing: A Modest Proposal' (1997) 22 YaleJIntlL 243; Hathaway and Neve (n 5). A Global Action Platform and Fund for Forced Migrants was proposed in July 2016, as a mechanism to implement the yet to be adopted Global Compact on Refugees (discussed below): see TA Aleinikoff and S Cliffe, 'A Global Action Platform and Fund for Forced Migrants: A Proposal' (25 July 2016) Netzwerk Flüchtlingsforschung <http://fluechtlingsforschung.net/a-global-action-platform-and-fund-forforced-migrants-a-proposal/>. For a discussion of other past proposals see P Wall, 'A New Link in the Chain: Could a Framework Convention for Refugee Responsibility Sharing Fulfil the Promise of the 1967 Protocol?' (2017) 29(2) IJRL (in press); B Cook, 'Method in Its Madness: The Endowment Effect in an Analysis of Refugee Burden-Sharing and a Proposed Refugee Market' (2004) 19 GeoImmigrLJ 333, 347ff; T Kritzman-Amir, 'Not in My Backyard: On the Morality of Responsibility Sharing in Refugee Law' (2009) 34 BrooklynJIntlL 355.

7 See eg the pledges made at a 2016 conference on resettlement for Syrian refugees: UNHCR, 'Summary of Key Outcomes: 30 March 2016 High Level Meeting on Global Responsibility Sharing through Pathways for Admission of Syrian Refugees' (14 April 2016). Over the previous three years, such meetings secured offers of more than 201,000 places for Syrian refugees: V Türk, 
predictably allocate responsibilities between States at a global level has still not been agreed.

On 19 September 2016, the UN General Assembly held its first-ever HighLevel Summit on Addressing Large Movements of Refugees and Migrants to address this and related questions. It was a significant and timely opportunity for the international community to adopt concrete commitments with respect to responsibility-sharing. ${ }^{8}$ Indeed, the zero draft of the political declaration (which, in amended form, became the New York Declaration for Refugees and Migrants and the Comprehensive Refugee Response Framework) included a Global Compact on Responsibility Sharing for Refugees which 'underline[d] the centrality of the principle of responsibility-sharing in ensuring effective refugee protection', ${ }^{9}$ 'recognize[d] that international cooperation and solidarity in shouldering the burden are fundamental in assisting States faced with large-scale refugee displacement in hosting refugees', ${ }^{10}$ and 'commit[ted] to an equitable sharing of responsibility for hosting and supporting refugees, while taking account of differing capacities and resources among States'. ${ }^{11}$

However, the finally-agreed text of the non-binding New York Declaration is comparatively muted. First, the proposed Global Compact on Responsibility Sharing for Refugees, which was supposed to be a key outcome of the UN Summit, has been postponed for two years; when it is adopted, it will simply be the Global Compact on Refugees (with no mention of responsibilitysharing in the title). ${ }^{12}$ Second, rather than firmly committing States to 'an equitable sharing of responsibility', the Declaration instead commits them to a 'more equitable sharing of burden and responsibility', taking into account not only their differing capacities and resources but also their existing contributions. ${ }^{13}$ Third, while the Declaration importantly reaffirms States' existing legal commitments, it does not expand them. Nor does it contain clear action points, accountability mechanisms or targets. ${ }^{14}$

'Prospects for Responsibility Sharing in the Refugee Context' (2016) 4 Journal on Migration and Human Security 45, 56. For more details of States' recent responsibility-sharing efforts, see UNHCR, 'Note on International Protection: Report of the High Commissioner', UN Doc A/ AC.96/1156 (12 July 2016) paras 8-9.

${ }^{8}$ For more information, see the UN Summit website: <http://refugeesmigrants.un.org/ summit>.

9 Zero Draft of a Global Compact on Responsibility Sharing for Refugees, attachment to a letter from the co-facilitators of the UN summit, (New York, 30 June 2016) para $6<$ http://www.unhcr.org/ events/conferences/578369114/zero-draft-global-compact-responsibility-sharing-refugees.html>. In the Declaration that was ultimately adopted (n 1), States more generally 'underline the centrality of international cooperation to the refugee protection regime' (para 68, emphasis added).

${ }^{10}$ Zero Draft of a Global Compact (n 9) para 7. In the Declaration that was adopted (n 1), States 'recognize the burdens that large movements of refugees place on national resources, especially in the case of developing countries' (para 68).

11 Zero Draft of a Global Compact (n 9) para 12.

12 New York Declaration (n 1) para $19 . \quad 13$ ibid para 68 (emphasis added).

14 J McAdam, 'Filling up or Emptying the Glass? Musings on the 19 September Refugee Summit' (Andrew \& Renata Kaldor Centre for International Refugee Law blog, 5 September 
As Lebanon's Ambassador to the UN, Nawaf Salam, observed after the UN Summit: 'There are no commitments in terms of responsibility-sharing, no agreement on relocation of refugees, no real commitment to [the creation of] development funds that could address the needs of refugee and host communities.' 15 Indeed, a joint statement from the co-hosts of President Obama's Leaders' Summit, held the day after the UN Summit, recognized that 'no routine mechanism exists yet to facilitate the kind of voluntary responsibility-sharing for refugees that was demonstrated today'. ${ }^{16}$

All this gives rise to a number of questions. Why did the outcomes of the UN Summit fall short of the expectations, especially given global displacement numbers and recognition of the need for greater action? How committed are States to international cooperation and responsibility-sharing? Do States understand these concepts in the same way as the UN and legal experts? It is clear that the success of any responsibility-sharing mechanism will depend on its acceptance and implementation by States. ${ }^{17}$ Indeed, many of the proposals made over the years to promote more equitable responsibility-sharing, including the zero draft's proposed Global Compact, have been more ambitious than States have been willing to accept. As noted by Elizabeth Ferris, an academic who was seconded to work with the UN Summit's Special Adviser, Karen AbuZayd, in the lead-up to the Summit, 'academic journals are filled with bold, ambitious proposals that have zero chance of success in the "real world" of politics and diplomacy."18

Against this backdrop, this article examines statements made by States at various UN fora over the past decade to shed light on their understandings of, and positions with respect to, international responsibility-sharing. It seeks to provide a unique insight into the meaning of responsibility-sharing and international cooperation from the perspective of individual States, which cannot be gleaned from collective statements or soft law instruments. As

2016 ) <http://www.kaldorcentre.unsw.edu.au/publication/filling-or-emptying-glass-musings-19september-refugee-summit>. While the Declaration is in legal terms a non-binding resolution of the UN General Assembly, the title of 'Declaration' indicates that it is 'a solemn instrument resorted to only in very rare cases relating to matters of major and lasting importance where maximum compliance is expected': UN Commission on Human Rights, 'Use of the Terms "Declaration" and "Recommendation": Memorandum of the Office of Legal Affairs', UN Doc E/ CN.4/L.610 (2 April 1962) para 5.

15 J Borger and P Kingsley, 'Swift Response to Refugee Crisis Rests on Obama after UN Talks Fail' The Guardian (20 September 2016) < https://www.theguardian.com/world/2016/sep/18/ refugee-crisis-rests-on-obama-summit-un-talks-fail $>$.

16 'Joint Statement on Leaders' Summit on Refugees' (The White House, Office of the Press Secretary, 20 September 2016) <https://www.whitehouse.gov/the-press-office/2016/09/20/jointstatement-leaders-summit-refugees $>$. The statement was made by the governments of Canada, Ethiopia, Germany, Jordan, Mexico, Sweden and the United States.

17 Kritzman-Amir (n 6) 388 citing Schuck (n 6) 271.

18 E Ferris, 'The Global Summit on Refugees and Migrants: The Pesky Issue of Level of Ambition' (Andrew \& Renata Kaldor Centre for International Refugee Law blog, 14 September 2016) <http://www.kaldorcentre.unsw.edu.au/publication/global-summit-refugees-and-migrantspesky-issue-level-ambition>. 
Garlick observes of UNHCR's Executive Committee Conclusions, adopted by States: "ExCom has referred to "burden-sharing" repeatedly over the years, in strongly-worded and ambitious terms. But the unequivocal language on the importance and urgency of burden-sharing in several ExCom texts has concealed deep divisions emerging in some of the discussions between developing and industrialised States. ${ }^{19}$

As a study in international law, the article focuses exclusively on responsibility-sharing at the global level rather than in regional schemes, such as those in Africa, Latin America or the European Union. Each of these has particular nuances specific to the historical, political and social context, as well as the empirical nature of refugee movements in those areas. They may also be influenced by differing concepts of (regional) solidarity, considerations of geography and financial concerns. ${ }^{20}$ Further, it should be noted that in some contexts - such as rescue at sea-calls have been made for greater international cooperation to share burdens and responsibilities through regional arrangements and mechanisms. ${ }^{21}$

After briefly exploring the issue of terminology with respect to responsibilitysharing, the article examines States' understandings of this principle in the context of international refugee protection. It focuses on two main methods of sharing responsibilities: the provision of financial and other assistance to host countries, and the admission of refugees. It then considers the extent to which States perceive responsibility-sharing to be an obligation, as opposed to a voluntary undertaking, and analyses this in light of the views of various commentators. Finally, the article discusses the principle of common but differentiated responsibilities, a concept drawn from international

19 M Garlick, Solidarity under Strain: Solidarity and Fair Sharing of Responsibility in Law and Practice for the International Protection of Refugees in the European Union (Radboud University Nijmegen, PhD thesis, 2016) 53. The majority of UNHCR Executive Committee Conclusions address burden- and/or responsibility-sharing in some way. Some of the key Executive Committee Conclusions include No 15 (XXX) (1979); No 77 (XLVI) 1995, para (o); No 80 (XLVII) 1996, paras (e); No 85 (XLIX) 1998, para (p); No 87 (L) 1999, para (I); No 89(LI) (2000); No 100 (LV) 2004. A number of UN General Assembly (UNGA) resolutions also recognize the importance of burden- and/or responsibility-sharing, including UNGA Resolution on the United Nations Millennium Declaration, UN Doc A/RES/55/2 (2000); UNGA Resolution on Promotion of a Democratic and Equitable International Order, UN Doc A/RES/56/151 (2001); UNGA Resolution on the Promotion of a Democratic and Equitable International Order, UN Doc A/ RES/57/213 (2002); UNGA Resolution on the Promotion of a Democratic and Equitable International Order, UN Doc A/RES/59/193 (2004). A more extensive list can be found in A Hurwitz, The Collective Responsibility of States to Protect Refugees (Oxford University Press 2009) 143, fn 94.

${ }^{20}$ For a good overview of regional responsibility-sharing, see V Türk and M Garlick, 'From Burdens and Responsibilities to Opportunities: The Comprehensive Refugee Response Framework and a Global Compact on Refugees' (2016) 28 IJRL 656, 666-71.

${ }^{21}$ UNHCR, 'Background Paper,' High Commissioner's Dialogue on Protection Challenges: Protection at Sea (11 November 2014) 8. 
environmental law, and considers whether and how it might apply to international refugee law.

The article's methodology entailed an exhaustive review of States' interventions over the past decade at UNHCR's Executive Committee meetings and before sessions of the Third Committee of the General Assembly (during which UNHCR's annual report was examined), ${ }^{22}$ as well as at the relevant roundtables of the 2016 UN Summit (where available). States' pledges at the 2011 Ministerial Meeting facilitated by UNHCR to mark the 60th anniversary of the 1951 Refugee Convention and the 50th anniversary of the 1961 Convention on the Reduction of Statelessness were also analysed, but nothing of particular pertinence emerged. Overall, the statements: (a) reveal the extent to which States regard responsibility-sharing as a legal duty, as opposed to a more general soft law principle; (b) shed light on what they understand its content to be; and (c) give clues as to the likelihood of the 2018 UN Global Compact on Refugees reflecting any new cooperative framework.

There are, of course, certain limitations to this research approach-most notably the fact that States are unlikely to voluntarily endorse, on record, a principle that they do not regard as legally binding. Indeed, most of the statements identified that advocated responsibility-sharing as a binding obligation were made by developing States, many of which were hosting large numbers of refugees at the time. It was often the same States, year after year, repeating similar calls to the international community, no doubt in search of greater solidarity and assistance. Nevertheless, developing States were not alone in this call, and were sometimes joined by developed States that were already demonstrating solidarity with host countries and were eager to encourage others to follow suit.

\section{TERMINOLOGY}

'International cooperation' is a broad term that is used in a number of different contexts, including, but also extending beyond, international refugee law. ${ }^{23}$ It is a core objective of the UN Charter and is key to achieving international peace

\footnotetext{
22 Reviewing States' interventions over a 10-year period enabled us to keep the findings up-todate and relevant, while also capturing changes over time. A keyword search of interventions before the UN General Assembly and Security Council was also conducted, with no set timeframe. This gave rise to some-although not extensive-useful results.

23 As explained by Angola in a statement before the UN Security Council (UNSC) in 2016, '[i]nternational cooperation under United Nations auspices comprises, inter alia, the fight against terrorism and international crime, human rights, social and economic development, climate change, epidemics, humanitarian assistance and migration:' UNSC, 7621st Meeting, UN Doc S/ PV.7621 (15 February 2016) 7 (Mr Augusto, Angola). Burden-sharing is also used in other contexts, such as defence and the environment: A Suhrke, 'Burden-Sharing during Refugee Emergencies: The Logic of Collective versus National Action' (1998) 11 JRS 396, 399-402. For environmental protection treaty examples of States' obligations to act in solidarity, shared extraterritorial zones, and trade and development, see Türk and Garlick (n 20) 661.
} 
and security. ${ }^{24}$ Generally speaking, international cooperation refers to two or more States working together towards a common goal. ${ }^{25}$ According to a report of a UNHCR-facilitated meeting of experts, '[i]nternational cooperation is best understood as a principle and methodology.' 26 Burdensharing and responsibility-sharing can be understood as particular forms of international cooperation, or as objectives thereof, arising in the context of refugee protection. ${ }^{27}$ These concepts have not been clearly defined, ${ }^{28}$ and as examined below, States adopt a variety of interpretations as to what they entail in practice. Generally speaking, burden-sharing relates to alleviating the pressure on States that are hosting large numbers of refugees, ${ }^{29}$ and responsibility-sharing relates to the recognition that refugee protection is a global responsibility. ${ }^{30}$

The term 'burden-sharing' has met with some controversy since it may imply that refugees constitute a burden for their host countries. ${ }^{31}$ This has prompted a shift towards the term 'responsibility-sharing.' For example, in the context of the Mexico Plan of Action - a continent-wide framework for the protection

24 See Charter of the United Nations (adopted 26 June 1945, entered into force 24 October 1945) 1 UNTS XVI (UN Charter) arts 1(3), 56; Declaration on Principles of International Law concerning Friendly Relations and Co-operation among States in accordance with the Charter of the United Nations, UNGA res 2625 (XXV) (24 October 1970) art 1.

25 According to Wolfrum, international cooperation is 'the voluntary coordinated action of two or more States which takes place under a legal régime and serves a specific objective': R Wolfrum, 'International Law of Cooperation' in Rudolf Bernhardt (ed), Encyclopaedia of Public International Law, vol 2 (North-Holland 1995) 1242.

${ }^{26}$ UNHCR 'International Cooperation to Share Burdens and Responsibilities: Summary Conclusions' (Expert Meeting, Amman, Jordan, 27-28 June 2011) 2.

27 For example, the New York Declaration (n 1) para 11 (emphasis added) states: 'We acknowledge a shared responsibility to manage large movements of refugees and migrants in a humane, sensitive, compassionate and people-centred manner. We will do so through international cooperation, while recognizing that there are varying capacities and resources to respond to these movements.'

${ }^{28}$ Fonteyne describes burden-sharing as 'at best an ill-defined concept of an essentially collective nature': J-P L Fonteyne, 'Burden-Sharing: An Analysis of the Nature and Function of International Solidarity in Cases of Mass Influx of Refugees' (1983) 8 AustYBIL 162, 185.

${ }^{29}$ Milner describes burden-sharing as 'the principle through which the diverse costs of granting asylum assumed by the host state are more equitably divided among a greater number of States': JHS Milner, Refugees, the State and the Politics of Asylum in Africa (Palgrave Macmillan 2009) 39. Thielemann characterizes international burden-sharing as 'the question how the costs of common initiatives or the provision of public goods should be shared between states': ER Thielemann, 'Between Interests and Norms: Explaining Burden-Sharing in the European Union (2003) 16 JRS 253, 253. Gottwald explains that 'States, notably developing countries hosting larger numbers of refugees, often use the term "burden-sharing" to emphasize the perceived and real inequalities in the distribution of direct and indirect costs that accrue when dealing with refugees both in situations of mass influx and in long-standing refugee situations.' See M Gottwald, 'Burden Sharing and Refugee Protection' in E Fiddian-Qasmiyeh, G Loescher, K Long and N Sigona (eds), The Oxford Handbook of Refugee and Forced Migration Studies (Oxford University Press 2014) $525,527$.

30 Some have interpreted this differently. For example, Hathaway and Neve define responsibility-sharing as providing safe and humane protection to refugees, and burden-sharing as apportioning the fiscal costs of meeting protection needs: Hathaway and Neve (n 5) 144-5.

31 See eg Wall (n 6) fn 17. 
of displaced people adopted by 20 governments in 2004-Harley recalled that participating States 'emphasized their humanitarian duty to work positively together and to share the responsibility for protecting refugees', noting that previous usages of 'burden-sharing' had promoted a negative perception of refugees. ${ }^{32}$

Humanitarian organizations tend to prefer the term 'responsibility-sharing' since it implies 'a more positive image of refugees and a stronger framework for international cooperation'. ${ }^{33}$ Indeed, former UNHCR Assistant High Commissioner for Protection, Erika Feller, has explained that the shift from the language of 'burden-sharing' to 'responsibility-sharing' recognizes that refugees are part of the solution, not just a 'problem' ${ }^{34}$ According to Türk and Garlick:

'Responsibility-sharing' casts refugees in a more favourable light, as potential contributors and assets for their host societies and as the holders of rights that create correlating responsibilities for States. States bearing 'burdens' may see themselves as passive recipients of those arriving and seeking protection; while 'responsibility' can be seen to imply legal obligations and a requirement to take positive action. ${ }^{35}$

At an Expert Meeting in 2011, UNHCR noted that:

The focus on 'international cooperation', rather than other terms such as 'responsibility-sharing', 'burden-sharing' or 'international solidarity', was welcomed. It was felt that a lengthy discussion on terminology (especially on the merits of 'burden' versus 'responsibility' sharing), at the expense of making concrete progress on enhancing cooperation in practice, needs to be avoided..$^{36}$

It should, however, be noted that 'international cooperation' in the refugee context is not limited to burden- and responsibility-sharing. For example, it has also been used by States in discussions about monitoring and managing migration, ${ }^{37}$ strengthening border protection and control measures, ${ }^{38}$

32 T Harley, 'Regional Cooperation and Refugee Protection in Latin America: A "South-South" Approach' (2014) 26 IJRL 32, 34. The objectives of international cooperation and responsibility-sharing are not fostered by collaborative deterrence mechanisms (cf New York Declaration (n 1) para 24); see, also, examples in the seven-part typology in T GammeltoftHansen and JC Hathaway, 'Non-Refoulement in a World of Cooperative Deterrence' (2015) 53 ColJTransntlL 253.

33 Gottwald (n 29) 525.

34 E Feller, 'International Refugee Protection 50 Years On: The Protection Challenges of the Past, Present and Future' (2001) 83 IRRC 581, 599.

35 Türk and Garlick (n 20) 665.

36 UNHCR Expert Meeting (n 26) 2.

37 Address by HE Hon WS Ruto, EGH Deputy President of the Republic of Kenya during the Co-Chairing of the Round Table 3 on 'International Action and Co-operation on Refugees and Migrants and Issues Related to Displacement: The Way Ahead', at the High Level Meeting of the General Assembly to Address Large Movements of Refugees and Migrants (UN, New York, 19 September 2016) para 12.

38 ibid. 
addressing mixed migration, ${ }^{39}$ and combatting human smuggling and trafficking. ${ }^{40}$

The terms 'burden-sharing' and 'responsibility-sharing' both continue to be used by States ${ }^{41}$ and UNHCR ${ }^{42}$ in various fora. For example, in the New York Declaration, States committed to 'a more equitable sharing of the burden and responsibility for hosting and supporting the world's refugees.' 43 States have sometimes also referred to the need for greater international solidarity with countries that are hosting large numbers of refugees, or have called more generally for enhanced international cooperation without specifically referring to burden- or responsibility-sharing.

This article predominantly uses the term responsibility-sharing, unless citing States that have used other terms. When the principle of international cooperation is referred to, this should be interpreted to mean international cooperation to share the responsibility for refugee protection.

\section{WHAT DOES INTERNATIONAL COOPERATION ENTAIL WITH RESPECT TO REFUGEE PROTECTION?}

It is commonly accepted that international cooperation in the context of refugee protection is not the subject of any binding legal agreement. ${ }^{44}$ While the importance of international cooperation is emphasized in the Preamble to the 1951 Convention, ${ }^{45}$ no guidance is given as to what this actually means. This is due to the fact that the Convention was not designed to address international cooperation in any detail. ${ }^{46}$ Indeed, at the time of its drafting, States rejected a

39 UNHCR Executive Committee, 61st session, Summary Record of the 644th Meeting, UN Doc A/AC.96/SR.644 (23 May 2011) para 63 (Ms Kgasi, South Africa).

40 See eg UNHCR Executive Committee, 65th session, Summary Record of the 682 nd Meeting, UN Doc A/AC.96/SR.682 (13 October 2014) para 9 (Ms Nielsen, Denmark); UNHCR Executive Committee, 66th session, Summary Record of the 689th Meeting, UN Doc A/AC.96/SR.689 (12 October 2015) para 36 (Ms Laurin, France).

41 Based on an analysis of statements made by States over the past 10 years at meetings of UNGA's Third Committee and UNHCR's Executive Committee.

42 For example, with respect to burden-sharing, at the 2015 meeting of UNHCR's Executive Committee, the Assistant High Commissioner for Protection stated that 'a global agreement on predictable and equitable burden-sharing was urgently needed to resolve the current problems': UNHCR Executive Committee, 66th session, Summary Record of the 691st Meeting, UN Doc A/AC.96/SR.691 (13 October 2015) para 14. UNHCR's 2016 Note on International Protection 'emphasizes the themes of international cooperation, solidarity and responsibility- and burdensharing': Note on International Protection (n 7) para 4 and Part II.

43 New York Declaration (n 1) para 68; see also Executive Committee Conclusion No 112 (LXVII) on International Cooperation from a Protection and Solutions Perspective (6 October 2016) Preamble.

${ }^{44}$ See eg Schuck (n 6) 254 (fns omitted); T Kritzman-Amir and Y Berman, 'Responsibility Sharing and the Rights of Refugees: The Case of Israel' (2010) 41(3) GeoWashIntlLRev 619, 633.

45 Convention relating to the Status of Refugees (adopted 28 July 1951, entered into force 22 April 1954) 189 UNTS 137, Preamble.

46 The 1951 Convention 'cannot be held accountable for what it has not achieved in relation to problems for which it was never intended as a response': Feller (n 34) 590. See also Türk (n 7) 47, 
proposal by the then UN Secretary-General to formally cooperate by 'agreeing to receive a certain number of refugees in their territory'. ${ }^{47}$

According to the outcomes of a UNHCR-facilitated meeting of experts in 2011, international cooperation 'can be manifested in many forms, including material, technical or financial assistance, as well as physical relocation of asylum-seekers and refugees. ${ }^{48}$ Indeed, international cooperation to share burdens and responsibilities is generally broken down by UNHCR and commentators into two main categories: the provision of financial and other assistance to host countries, and the admission of refugees, most commonly through resettlement. ${ }^{49}$ In addition to financial support, this first category can include technical assistance and capacity-building, ${ }^{50}$ consultation and sharing of information. ${ }^{51}$ Some view burden- or responsibility-sharing even more broadly. For example, Gottwald suggests that the scope of burden-sharing has widened over the past 60 years, with practitioners increasingly acknowledging that the concept of 'burden' needs to extend to all phases of displacement, including preventing and finding durable solutions to displacement..$^{52}$

The nature of responsibility-sharing will also vary depending on context. With respect to rescue at sea, for example, it may entail financial, material, technical or other capacity-building assistance; assumption of responsibility by non-disembarking States for status determination, protection or durable

where he argues that the 'deeper issue' is 'the failure of political will' to abide by or fully implement the Convention and address the root causes of displacement.

47 UN Secretary-General: Ad Hoc Committee on Statelessness and Related Problems, 'Status of Refugees and Stateless Persons: Memorandum by the Secretary-General', UN Doc E/AC.32/2 (3 January 1950), Annex, Preliminary Draft Convention relating to the Status of Refugees (and Stateless Persons), art 3(2), cited in GS Goodwin-Gill and J McAdam, The Refugee in International Law (3rd edn, Oxford University Press 2007) 362 fn 42.

${ }^{48}$ UNHCR Expert Meeting (n 26) 2.

49 In 2012, the UN High Commissioner for Refugees stated that ' $[\mathrm{u}]$ pholding and sustaining the right to asylum required strong, timely and sustained international solidarity and burden-sharing, in the form of financial, technological and political support, and enhanced resettlement programmes': UNGAOR, Third Committee, 67th session, 32nd Meeting, UN Doc A/AC.3/67/SR.32 (28 December 2012) para 3 (Mr Guterres, UN High Commissioner for Refugees). For a detailed description and analysis of 'fiscal' and 'physical' burden-sharing, see Hurwitz (n 19) 147-56; A Betts, 'International Cooperation in the Global Refugee Regime' (Global Economic Governance Programme, Oxford, Working Paper 2008/44, 2008) 5. Gregor Noll included a third element, the harmonization of policy: see G Noll, Negotiating Asylum: The EU Acquis, Extraterritorial Protection and the Common Market of Deflection (Martinus Nijhoff 2000).

${ }^{50}$ Hurwitz (n 19) 146. See, for example, the work of the European Asylum Support Office (EASO), which constitutes the most well-developed effort by States to institutionalize technical assistance and support at the regional level.

51 The latter two were mentioned in Kritzman-Amir and Berman (n 44) 630. In the durable solutions section of the Comprehensive Refugee Response Framework, Annex 1 of the New York Declaration (n 1) para 14(a), 'third countries' commit to 'sharing best practices, providing refugees with sufficient information to make informed decisions and safeguarding protection standards'.

${ }^{52}$ See Gottwald (n 29) 529. As an interesting counterpoint, the New York Declaration's commitments to cooperation on migration contain a much wider range of action points: New York Declaration (n 1) paras 41-43, 54, 58. 
solutions; and/or direct in-kind assistance or participation in joint operations or processes. ${ }^{53}$

For the most part, States' calls for responsibility-sharing examined for this article fit within the 'financial' and 'physical' categories, as discussed below. For example, the representative from Brazil explained at the $2016 \mathrm{UN}$ Summit that: 'A balanced sharing of responsibilities ... calls for two kinds of action: to help host countries in the developing world to ensure that these countries can guarantee basic rights for refugees; and to expand admission channels so that a proportion of refugees currently in overloaded developing countries can seek protection elsewhere.' 54

However, States, too, sometimes take this even further. ${ }^{55}$ For example, they have called for international cooperation or burden- and responsibility-sharing to address the root causes of displacement, ${ }^{56}$ to promote development activities in countries of origin and host countries, ${ }^{57}$ and to provide political support to

${ }^{53}$ UNHCR (n 21) 8. For a description of proposed operational tools to enhance cooperative responses to rescue at sea situations involving refugees and asylum seekers, including a Model Framework for Cooperation, see UNHCR, 'Refugees and Asylum-Seekers in Distress at SeaHow Best to Respond?: Summary Conclusions' (Expert Meeting, Djibouti, 8-10 November 2011).

${ }^{54}$ See eg statement by HE Alexandre de Moraes, Minister of Justice and Citizenship for Brazil, Round Table 4 on 'Global Compact for Responsibility-Sharing for Refugees: Respect for International Law' at the High Level Meeting of the General Assembly to Address Large Movements of Refugees and Migrants (UN, New York, 19 September 2016). See also UNHCR Executive Committee, 59th Session, Summary Record of the 618th Meeting, UN Doc A/AC.96/ SR.618 (7 November 2008) paras 29-30 (Mr Witten, United States of America), who noted five principles that might guide the work of the Executive Committee: 'The second principle was burden sharing, which required not just financial contributions but also States' full participation in finding solutions for refugees.'

${ }_{55}$ For a recent summary of what international cooperation entails from the perspective of States, see Executive Committee Conclusion No 112 (n 43).

${ }^{56}$ See eg UNGAOR, Third Committee, 70th session, 41st Meeting, UN Doc A/C.3/70/SR.41 (8 December 2015) para 44 (Mr Baomran, United Arab Emirates) and para 55 (Mr Teffo, South Africa); UNGOAR, Third Committee, 65th session, 38th Meeting, UN Doc A /C.3/65/SR.38 (13 December 2010) para 66 (Mr Zhou Ningyu, China); UNHCR Executive Committee 61st session, Summary Record of the 643rd Meeting, UN Doc A/AC.96/SR.643 (15 October 2010) para 7 (Ms Farani Azevêdo, Brazil). According to Suhrke (n 23) 399-402, 'States would have more incentives to accept responsibility-sharing schemes if they simultaneously had some assurance that they could control events that produce refugees.' In setting out what cooperation to share burdens and responsibilities means, Gottwald (n 29) 535 includes 'efforts to resolve conflicts and prepare the ground for durable solutions'. Executive Committee Conclusion no. 112 (n 43) para 8 called upon States and other relevant actors 'to commit themselves, in the spirit of international solidarity and burden-sharing, to comprehensive, multilateral and multi-sectoral collaboration action' in addressing the root causes of protracted refugee situations, ensuring that people are not compelled to flee in the first place, and resolving protracted situations.

${ }^{57}$ See eg UNGOAR, Third Committee, 66th session, 38th Meeting, UN Doc A/C.3/66/SR.38 (10 February 2012) para 34 (Mr Sefue, Tanzania), where Tanzania "called on the international community to put the principles of international cooperation, solidarity and responsibility sharing into action by assisting refugee host communities, resettling more Africans and, more broadly, supporting the work of States and development actors to promote sustainable and equitable growth'. See also UNGOAR, Third Committee, 62nd session, 40th Meeting, UN Doc A/C.3/62/ SR.40 (17 January 2008) para 41 (Mr El Amin, Sudan), where Sudan noted 'that burden-sharing should facilitate the transition from emergency assistance and relief activities to development activities in all areas affected by wars'. 
host countries. ${ }^{58}$ Despite its own questionable human rights record, China has asserted that burden-sharing includes demonstrating tolerance and respecting and promoting the human rights of refugees. ${ }^{59}$ States, both individually and through UNHCR's Executive Committee, ${ }^{60}$ have also called for international cooperation with respect to internally displaced persons (IDPs) ${ }^{61}$ and stateless people ${ }^{62}$ (which goes beyond the scope of this article).

The majority of calls for increased burden- and responsibility-sharingparticularly direct calls for financial assistance and physical relocation-have come from developing countries, most of which host refugees. ${ }^{63}$ While such calls have usually referred to the international community generally, they have sometimes been directed specifically at developed countries. ${ }^{64} \mathrm{By}$ contrast, when developed countries refer to responsibility-sharing, it has mostly been in the more general context of acknowledging the efforts of host countries, ${ }^{65}$ calling for greater international cooperation generally, ${ }^{66}$ emphasizing the importance of burden-sharing, ${ }^{67}$ reinforcing the principles of

58 UNGOAR, Third Committee, 70th session, 40th Meeting, UN Doc A/C.3/70/SR.40 (11 January 2016) para 99 (Mr Moussa, Egypt): 'Assistance should be provided to host countries to continue to provide protection to millions of refugees on behalf of the international community, to include greater material, financial and political support.' The UN High Commissioner for Refugees has similarly noted 'that increased international burden-sharing and solidarity were needed in order to enhance the efforts of refugee-hosting countries, through financial and political support and enhanced resettlement programmes': see UNHCR Executive Committee 63rd session, Summary Record of the 657th Meeting, UN Doc A/AC.96/SR.657 (8 October 2012) para 20 (Mr Guterres, UN High Commissioner for Refugees).

59 UN Doc A/C.3/70/SR.41 (n 56) para 29 (Mr Yao Shaojun, China).

60 A 2016 Executive Committee Conclusion recalls 'that international cooperation is important for States with internally displaced persons, stateless populations, as well as other people of concern to UNHCR': see Executive Committee Conclusion No 112 (n 43) Preamble.

${ }^{61}$ For example, the Russian Federation urged that 'States must stand in solidarity and assume responsibility for assisting [a State that is home to IDPs], but at its request and with its consent': UN Doc A/C.3/62/SR.40 (n 57) para 57 (Mr Goltyaev, Russian Federation). The United States noted that ' $[\mathrm{t}]$ he situation of internally displaced Iraqis was precarious', asserting that 'Governments had a collective responsibility to help host countries in the region to provide education and health care to that population': UNHCR Executive Committee, 58th session, Summary Record of the 609th Meeting, UN Doc A/AC.96/SR.609 (4 April 2009) para 21 (Ms Sauerbrey, United States of America).

${ }^{62}$ UNHCR Executive Committee, 60th session, Summary Record of the 628th Meeting, UN Doc A/AC.96/SR.628 (8 July 2010) para 24 (Mr Rudd, Prime Minister of Australia).

63 This was particularly the case in the General Assembly, as opposed to during UNHCR's Executive Committee meetings. It should also be noted that, overall, statements regarding international cooperation were made by a limited number of States, most notably the Islamic Republic of Iran, Egypt, Kenya, Pakistan, Thailand, China and Jordan.

${ }_{64}$ See eg UN Doc A/C.3/70/SR.41 (n 56) para 29 (Mr Yao Shaojun, China); UN Doc A /C.3/65/ SR.38 (n 56) para 64 (Ms Gendi, Egypt); UNHCR Executive Committee, 62nd session, Summary Record of the 648th Meeting, UN Doc A/AC.96/SR.648 (13 January 2012) para 27 (Mr Mebazaa, President ad interim of the Republic of Tunisia).

65 See eg UN Doc A/C.3/70/SR.40 (n 58) para 112 (Ms Halter, Switzerland).

66 See eg UNHCR Executive Committee, 58th session, Summary Record of the 615th Meeting, UN Doc A/AC.96/SR.615 (14 April 2009) para 12 (Mr Kroll, Germany); UN Doc A/C.3/70/SR.40 (n 58) para 1 (Mr Lykketoft, Denmark).

67 See eg UN Doc A/AC.96/SR.691 (n 42) para 17 (Ms Pollack, United States of America). 
burden- and responsibility-sharing, ${ }^{68}$ and/or noting that sharing the burden of protecting refugees is an on-going challenge. ${ }^{69}$ Indeed, host countries that perceive they are not receiving adequate assistance from the international community have described burden-sharing as "lofty rhetoric. ${ }^{70}$

\section{A. Financial Assistance}

Financial assistance to refugee-hosting countries has been described as the 'most convenient and common' way for burden-sharing to be effected ${ }^{71}$ and as 'the easiest form of sharing.' 72 Indeed, the provision of financial assistance, predominantly through donations to UNHCR, is the most conventional way for States (usually developed countries) to support overburdened host countries.

In their various statements, host countries have made clear that financial assistance must not only meet the immediate needs of refugees, but must also include assistance to minimize the adverse impact of refugee inflows on host countries. ${ }^{73}$ This has also been acknowledged by developed States and States collectively. ${ }^{74}$ For example, Sweden recognized that '[s]ince the massive inflows put serious strain on social services, the economy and the infrastructure of host countries, more needed to be done to share the burden and to enable host countries to continue taking in refugees' ${ }^{75}$

As might be expected, calls for responsibility-sharing in the form of financial assistance have most commonly been made by developing countries. ${ }^{76}$ This

${ }^{68}$ See eg UN Doc A/C.3/70/SR.40 (n 58) para 112 (Ms Halter, Switzerland).

69 See eg UNGOAR, Third Committee, 62nd session, 41st Meeting, UN Doc A/C.3/62/SR.41 (14 December 2007) para 63 (Mr Rees, United States of America).

70 ibid para 32 (Mr Elbahi, Sudan).

71 Hurwitz (n 19) 146. She also notes that this can include technical assistance and capacity building.

72 Suhrke (n 23) 407.

${ }^{73}$ UNSCOR, 55th session, 4219th Meeting, UN Doc S/PV.4219 (10 November 2000) 15 (Mr Ahmed, Bangladesh). See also UNHCR Executive Committee, 61st session, Summary Record of the 639th Meeting, UN Doc A/AC.96/SR.639 (15 October 2010) para 43 (Mr Elmi Bouh, Djibouti).

74 For example, the Final Statement of the UNHCR Executive Committee's 2013 High-Level Segment on Solidarity and Burden-Sharing with Countries Hosting Syrian Refugees calls upon the international community to provide direct aid to governments, provide financial and in-kind assistance to support refugees and host communities, and take into consideration 'the impact of refugees on country economies, societies, services, infrastructure, environment and security, in order to provide the assistance required': UNHCR Executive Committee, 64th session, Summary Record of the 668th Meeting, UN Doc A/AC.96/SR.668 (18 October 2013) para 42. This also called on the international community to ' $[\mathrm{u}] \mathrm{rge}$ development actors to consider initiatives and projects directed to host communities to ease the economic and social costs of hosting Syrian refugees'.

75 UNHCR Executive Committee, 58th session, Summary Record of the 610th Meeting, UN Doc A/AC.96/SR.610 (19 October 2007) para 59 (Mr Dahlgren, Sweden)

76 Examples include: UN Doc A/AC.96/SR.689 (n 40) para 20 (Mr Ahsan, Bangladesh); UNHCR Executive Committee, 66th session, Summary Record of the 685th Meeting, UN Doc A/AC.96/SR.685 (7 October 2015) para 10 (Mr Alghunaim, Observer for Kuwait); UNHCR Executive Committee, 61st session, Summary Record of the 641st Meeting, UN Doc A/AC.96/ SR.641 (11 October 2010) para 62 (Ms Eltaweel, Jordan); UN Doc A/C.3/70/SR.41 (n 56) para 
stems from the oft-cited reality that over 84 per cent of refugees are hosted by developing countries, ${ }^{77}$ and also ties into the discussion below concerning the differentiation of responsibilities according to capacity. Some developing States have made general calls to the international community to provide greater financial support to host countries, ${ }^{78}$ whereas others have called for assistance with respect to a particular cohort of refugees. ${ }^{79}$ In 2016, China said that 'countries that took in refugees and applied the principle of nonrefoulement should receive financial support. ${ }^{\prime} 0$

By contrast, developed States have rarely called for the international community to deliver greater financial contributions, apart from some key UNHCR donors that are keen to share responsibility for funding the organization in a more equitable manner. Finland, for example, noted in 2007 that Nordic countries provided almost 80 per cent of voluntary contributions to UNHCR and called on other donors to assume their share of the burden. ${ }^{81}$ The United States, which is UNHCR's biggest donor, has similarly noted that it is the obligation of Member States to adequately fund UNHCR. ${ }^{82}$

In addition to financial support, several States have called for responsibilitysharing in the form of technical assistance. According to Egypt, for example,

the provision of assistance to refugees, burdens and responsibilities must be shared. Developed countries should be encouraged to accept more refugees and provide technical and financial assistance to countries emerging from conflicts to help them build their institutional capacities and provide basic services to all their citizens. ${ }^{83}$

The United States has also recognized the importance of information-sharing, noting that ' $[\mathrm{g}] \mathrm{lobal}$ responsibility could not be properly shared without coordinated humanitarian responses. In that connection, data-sharing and coordination with the United Nations system were of key importance'.${ }^{84}$

58 (Ms Mballa Eyenga, Cameroon); UN Doc A/C.3/70/SR.40 (n 58) para 99 (Mr Moussa, Egypt); UNHCR Executive Committee, 56th session, Summary Record of the 592nd Meeting, UN Doc A/ AC.96/SR.592 (6 January 2012) para 15 (Mr Owusu-Ankomah, Ghana).

77 UNHCR Global Trends (n 4).

78 See eg UN Doc A /C.3/66/SR.38 (n 3 ) 2 para 36 (Mr Gaspar Martins, Angola).

79 See eg recent statements by countries hosting large numbers of Syrian refugees, such as Jordan and Turkey: UNHCR Executive Committee, 64th session, Summary Record of the 666th Meeting, UN Doc A/AC.96/SR.666 (14 October 2013) para 22 (Mr Davutoğlu, Minister for Foreign Affairs, Turkey); and UNSCOR, 70th session, 7588th Meeting, UN Doc S/PV.7588 (18 December 2015) 7 (Mr Judeh, Jordan).

${ }^{80}$ UNHCR Executive Committee, 67th session, Summary Record of the 695th Meeting, UN Doc A/AC.96/SR.695 (29 November 2016) para 18 (Mr Ma Zhaoxu, China).

81 UN Doc A/AC.96/SR.615 (n 66) para 36 (Ms Lescelius, Finland).

82 UN Doc S/PV.4219 (n 73) para 7 (Mr Cunningham, United States of America).

83 UN Doc A /C.3/65/SR.38 (n 56) para 64 (Ms Gendi, Egypt). See also UNGAOR, Third Committee, 69th session, 41st Meeting, UN Doc A/C.3/69/SR.41 (12 January 2015) para 36 (Mr Yao Shaojun, China).

${ }^{84}$ UNHCR Executive Committee, 64th session, Summary Record of the 669th Meeting, UN Doc A/AC.96/SR.669 (24 December 2013) para 12 (Mr Henshaw, United States of America). 


\section{B. Physical Responsibility-Sharing}

The three 'traditional' durable solutions for refugees are voluntary repatriation, local integration and resettlement. Providing complementary pathways for the admission (and stay) of refugees can take many different forms, however, including humanitarian visas, work or study opportunities, visa exemptions for certain groups, temporary evacuation schemes, labour mobility schemes and family reunification. ${ }^{85}$ Hurwitz has described the admission and reception of refugees as ' $[\mathrm{t}]$ he most radical and thereby least popular manner to relieve first asylum States from the heavy burden of receiving and protecting refugees'. ${ }^{86}$ Indeed, developed States appear to be much more inclined to provide financial assistance to host countries than to accept refugees; one statement by Japan even suggests that it understands international cooperation as being synonymous with monetary contributions. ${ }^{87}$

The most common means of physical responsibility-sharing requested by developing and/or host countries has been resettlement, with calls for quotas to be "commensurate with the number of refugees' 88 (and often the size of the population of the host country as well); for the resettlement process to be expedited through increased places; ${ }^{89}$ and for 'more flexible' resettlement criteria to be adopted. ${ }^{90}$ In requesting more resettlement places, some States have explained that voluntary repatriation is slow and they are unable to provide local integration solutions. ${ }^{91}$ For example, the representative of Thailand told the General Assembly in 2007 that '[w]hile voluntary repatriation, rather than resettlement, should be the preferred solution in dealing with displacement, the international community should share responsibility for providing third-country resettlement where repatriation was not feasible'. 92

85 See New York Declaration (n 1) para 79; Türk (n 7) 55-6; Executive Committee Conclusion No 112 (n 43) para 11. For a discussion of burden-sharing options for the EU with respect to Syrians, see P Fargues, 'Europe Must Take on Its Share of the Syrian Refugee Burden, but How?' (Migration Policy Centre, Policy Brief 2014/1) 4.

${ }^{86}$ Hurwitz (n 19) 146. Tunisia noted in 2012 that certain developed countries continued to 'balk at admitting refugees:' UN Doc A /C.3/66/SR.38 (n 57) para 61 (Ms Dali, Tunisia).

${ }^{87}$ In a statement before the General Assembly in 2015, the representative from Japan stated that '[i]ts international cooperation in that regard included \$50 million in emergency assistance to the Middle East and \$17 million to Africa': UN Doc A/C.3/70/SR.41 (n 56) para 8 (Mr Tsutsumi, Japan).

${ }^{88}$ UN Doc A/AC.96/SR.648 (n 64) para 40 (Mr Abdollahi, Islamic Republic of Iran).

${ }^{89}$ UNHCR Executive Committee, 65th session, Summary Record of the 680th Meeting, UN Doc A/AC.96/SR.680 (13 October 2014) para 4 (Mr Zolfaghari, Islamic Republic of Iran).

90 UNHCR Executive Committee, 57th session, Summary Record of the 605th Meeting, UN Doc A/AC.96/SR.605 (13 December 2006) para 23 (Mr Shirazi, Islamic Republic of Iran); UNHCR Executive Committee, 65th session, Summary Record of the 676th Meeting, UN Doc A/AC.96/SR.676 (7 October 2014) para 41 (Mr Getahun, Ethiopia).

${ }_{91}$ See eg UN Doc A/AC.96/SR.618 (n 54) para 46 (Mr Mohtaj, Islamic Republic of Iran); UN Doc A /C.3/66/SR.38 (n 57) para 21 (Mr Kimani, Kenya).

92 UN Doc A/C.3/62/SR.41 (n 69) para 58 (Mr Pramudwinai, Thailand). 
The limited number of developed States that have called for more resettlement places during the meetings examined-including by establishing new programmes - have tended to be resettlement countries themselves. While some of these States were presumably striving to relieve the burden on developing host countries, others appeared to be more interested in minimizing their own level of commitment: in a 2014 meeting of UNHCR's Executive Committee, for example, Australia stated that 'the burden of resettling refugees and displaced persons should not be restricted to a small group of wealthy countries'. ${ }^{93}$ Almost all of the countries calling for more resettlement over the past decade were in Europe and focused particularly on the European asylum system. ${ }^{94}$ However, in terms of offering places, several of the key resettlement countries over the same period were outside Europe. ${ }^{95}$ At the Leaders' Summit in New York on 20 September 2016, at least 18 countries across four continents committed to starting or expanding resettlement programmes, or announced plans to increase complementary pathways for refugees. ${ }^{96}$

Although commentators tend to focus on admission to a third country when analysing the 'physical relocation' component of responsibility-sharing, some States have called for international cooperation to facilitate voluntary repatriation and reintegration. 97 For example, Iran has noted that '[i]nternational cooperation with the country of origin was needed in particular to facilitate voluntary repatriation and reintegration';98 Bangladesh has 'stressed the importance of translating the burden-sharing principle into concrete financial measures and measures to facilitate repatriation';99 and Egypt has stated that

93 UN Doc A/AC.96/SR.680 (n 89) para 6 (Ms Southern, Australia).

94 UN Doc A/AC.96/SR.691 (n 42) para 19 (Ms Lindblad, Sweden); UNHCR Executive Committee, 62nd session, Summary Record of the 653rd Meeting, UN Doc A/AC.96/SR.653 (5 October 2001) para 74 (Mr Rytövuori, Finland). See also statements from Belgium, the Netherlands and Sweden concerning the proposed joint EU resettlement programme: UN Doc A/ AC.96/SR.639 (n 73) para 40 (Mr Van Meeuwen, Belgium); UNHCR Executive Committee, 60th session, Summary Record of the 629th Meeting, UN Doc A/AC.96/SR.629 (12 October 2009) para 44 (Mr Schaapveld, Netherlands); UN Doc A/AC.96/SR.628 (n 62) para 28 (Ms Ljunggren, Sweden).

95 In 2015, for example, 33 States offered resettlement or humanitarian admission, with the United States offering the highest number of resettlement places $(66,500)$. See UNHCR Global Trends (n 4) 3, 26. A decade ago, 15 countries offered resettlement places, with the United States, Australia, Canada and Sweden offering the highest number. See UNHCR, 2006 Global Trends: Refugees, Asylum-Seekers, Returnees, Internally Displaced and Stateless Persons (UNHCR 2007) 8.

96 'Fact Sheet on the Leaders' Summit on Refugees' (The White House, Office of the Press Secretary, 20 September 2016) <https://www.whitehouse.gov/the-press-office/2016/09/20/factsheet-leaders-summit-refugees $>$.

97 See eg UN Doc A/C.3/62/SR.40 (n 57) para 54 (Mr Attiya, Egypt); UN Doc A/AC.96/SR.689 (n 40) para 20 (Mr Ahsan, Bangladesh); UN Doc A/AC.96/SR.648 (n 64) para 40 (Mr Abdollahi, Islamic Republic of Iran); UN Doc A/C.3/70/SR.41 (n 56) para 41 (Ms Wardak, Afghanistan); UN Doc A/AC.3/67/SR.32 (n 49) para 48 (Ms Heptullah, India) and para 67 (Mr Selim, Egypt).

98 UN Doc A/AC.96/SR.648 (n 64) para 40 (Mr Abdollahi, Islamic Republic of Iran).

99 UN Doc A/AC.96/SR.689 (n 40) para 20 (Mr Ahsan, Bangladesh). 
'the principles of international solidarity and shared burdens and responsibilities must be applied, including in terms of allowing refugees to return to their countries of origin or to resettle in a third country'. ${ }^{100}$

More generally, a number of States have called for international cooperation and/or burden- and responsibility-sharing to provide durable solutions, ${ }^{101}$ including specifically with respect to protracted situations. ${ }^{102}$ Fonteyne argues that the provision of durable solutions may be a more critical aspect of international cooperation than the provision of financial and technical assistance. $^{103}$

\section{RESPONSIBILITY-SHARING: AN OBLIGATION OR A VOLUNTARY UNDERTAKING?}

The legal character of States' responsibilities with respect to responsibilitysharing and international cooperation has been the subject of considerable discussion and analysis. ${ }^{104}$ In 1983, Fonteyne argued that burden-sharing was a norm of customary international law, ${ }^{105}$ asserting also that UN Member States have some burden-sharing obligations deriving from the UN Charter: 'UN Member States' obligations with respect to UNHCR must include at least participation to a reasonable extent in the financing of the Office and its operations and UNHCR resettlement schemes.' 106

However, the more widely-held view is that while the principle of responsibility- or burden-sharing is a critical norm of international refugee law, it does not impose legally binding obligations on States. ${ }^{107}$ Garlick explains that, unlike the principle of international cooperation, burden-sharing

100 UN Doc A/C.3/62/SR.40 (n 57) para 54 (Mr Attiya, Egypt).

101 See, for example, UN Doc A/AC.96/SR.644 (n 39) para 72 (Mr Thananant, Thailand); UNHCR Executive Committee, 60th session, Summary Record of the 633rd Meeting, UN Doc A/AC.96/SR.633 (12 October 2009) para 33 (Mr Arias Palacio, Bolivarian Republic of Venezuela); UNHCR Executive Committee, 58th session, Summary Record of the 614th Meeting, UN Doc A/AC.96/SR.614 (6 November 2007) para 72 (Mr Bessedik, Algeria); UNHCR Executive Committee, 65th session, Summary Record of the 678th Meeting, UN Doc A/AC.96/SR.678 (9 October 2014) para 14 (Ms Iivula-Ithana, Namibia), speaking on behalf of the African Group.

102 See eg UN Doc A/AC.96/SR.633 (n 101) para 70 (Mr Felten, Germany) and para 81 (Mr Larsen (Denmark).

103 Fonteyne (n 28) 175-6.

104 For a detailed discussion of the various soft and hard law instruments, both regional and international, that affirm the importance of international cooperation and/or solidarity, see Türk and Garlick (n 20) 661-3.

105 Fonteyne (n 28) 184.

106 Ibid, 180. Fonteyne argues further that 'burden-sharing in a situation of massive refugee flow could even be seen as an essential component of a State's Charter obligations in relation to the primary purpose of the United Nations: the maintenance of international peace and security' (184).

107 For example, Kritzman-Amir and Berman (n 44) 633 argue that '[i]nternational law at its present stage, whether on the global level or on the regional level, contains no clear and legally binding guidelines for responsibility sharing'. According to Schuck (n 6) 272, 254 (fns omitted), the 'burden-sharing norm' is 'manifestly weak', and attempts by commentators to derive a norm of equitable burden-sharing from the principle of international solidarity 'are more in the nature of moral exhortation and prudential argument than expositions of authoritative legal principles'. 
to protect refugees is not contained in any international treaty. ${ }^{108}$ She also notes that recent inconsistent State practice is unlikely to support the case for a binding obligation in customary international law. ${ }^{109}$ Hurwitz agrees, explaining that the principle of solidarity and burden-sharing is best understood as belonging to the category of general soft law principles. ${ }^{110}$ However, given that burden-sharing is one of the 'founding principles' of international law, she argues that it 'must necessarily have some bearing on the conduct of States and international organisations'. ${ }^{111}$

More broadly, it has been argued that the principle of international cooperation (as opposed to burden-sharing) has some legal force. For example, Volker Türk and Madeline Garlick - two of UNHCR's most senior legal protection officials - maintain that a 'legal obligation for States to cooperate with each other in regard to refugee matters, directly among themselves and via cooperation with UNHCR, ... emerges from the UN Charter, UNHCR's Statute, and subsequent relevant UNGA resolutions in conjunction with the 1951 Convention, as well as other international refugee instruments and corresponding State practice'.112 However, they acknowledge that, without specific elaboration, it is very difficult to ascertain 'precisely what form and content such cooperation would take, and what States' respective contributions thereto should be'. ${ }^{113}$ In examining State practice, refugee scholars Goodwin-Gill and McAdam identify a 'significant level of practical cooperation ... even if material contributions and political or moral support for the displaced waver and formal obligations are elusive'. ${ }^{114}$

Even if it could be argued that responsibility-sharing is a legally binding norm, what would this mean in practice? How would States' obligations be measured? As Fonteyne explains:

All burden-sharing really requires is that the nations of the world, as a group, achieve a given result: the provision of material assistance to, and where necessary the removal of excessively burdensome refugee populations from the territory of, countries of first refuge. The obligations of individual States are thus by definition indirect and, one would say, not susceptible to a priori determination with any degree of specificity. ${ }^{115}$

This is where the concept of common but differentiated responsibilities may come into play, discussed further below.

\footnotetext{
108 Garlick (n 19) section 2.1.3.

109 ibid; Hurwitz (n 19) 161-2 also notes that practice in the last two decades has not been conclusive, particularly with respect to physical burden-sharing. Similarly, in 1997, Schuck (n 6) 246 noted that 'the emerging state responses to these burdens are seriously jeopardizing the viability of any meaningful regime of international human rights protection'.

110 Hurwitz (n 19) $163 . \quad 111$ ibid 164. 112 Türk and Garlick (n 20) 660. 113 ibid.

114 Goodwin-Gill and McAdam (n 47) 504 (fn omitted). $\quad{ }^{115}$ Fonteyne (n 28) 184.
} 


\section{A. The Position of States}

Analysis of statements by States over the course of the last decade shows a variety of positions as to the nature of their responsibilities to cooperate. Some have explicitly stated that they are not under any legal obligation to share the responsibility for refugee protection. Zambia, for example, has noted the apparent 'absence of binding legal obligations on the international community to contribute to the international protection of refugees'.116 Others have noted the need to convert the principles of solidarity and equitable burden-sharing into binding obligations, implying that this is not presently the case. ${ }^{117}$ Yet others have used relatively weak language, referring to the 'importance of' 118 or a 'need' for international cooperation and burden- and responsibility-sharing; ${ }^{119}$ noting that this is 'necessary';120 stating that the international community 'should' do more; ${ }^{121}$ and expressing 'hope' that the international community would show greater support ${ }^{122}$ or fulfil its responsibilities. ${ }^{123}$ Such language does not indicate a sense of obligation. In slightly stronger terms, some States have referred to the international community's 'joint' or 'collective' responsibility to assist overburdened host countries. ${ }^{124}$

A number of States have used firmer language in their calls for enhanced international cooperation, such as the term 'must', thereby implying that the international community has a responsibility to work together. They have stated, for example, that States (or the international community) 'must' strengthen their cooperation and coordination; ${ }^{125}$ share responsibilities for

116 UN Doc A/AC.96/SR.676 (n 90) para 16 (Mr Chilangwa, Zambia). In 1998 (ie prior to the decade under examination), Austria explained that ' $[\mathrm{b}]$ urden-sharing was of course not an obligation either in statutory or in customary international law, but many international instruments demonstrated a solid political commitment to that principle and to the principle of international solidarity': UNHCR Executive Committee, 49th session, Summary Record of the 525th Meeting, UN Doc A/AC.96/SR.525 (16 November 1998) para 46 (Mr Kreid, Austria), cited in Hurwitz (n 19) 162 fn 223.

117 UN Doc A /C.3/66/SR.38 (n 57) para 61 (Ms Dali, Tunisia).

118 See eg UN Doc A/AC.96/SR.676 (n 90) para 23 (Mr Mero, United Republic of Tanzania); UN Doc A/AC.96/SR.669 (n 84) para 12 (Mr Henshaw, United States of America).

119 UN Doc A/AC.96/SR.685 (n 76) para 58 (Ms Guenther, Germany); UN Doc A/C.3/70/SR.40 (n 58) para 1 (Mr Lykketoft, Denmark).

${ }_{120}$ UN Doc A/AC.96/SR.685 (n 76) para 36 (Mr Nsie Edang, Observer for Gabon).

121 See Eg UN Doc A/AC.96/SR.676 (n 90) para 25 (Mr Wu Hailong, China) and para 33 (Mr Manicom, Canada); UN Doc A/AC.96/SR.678 (n 101) para 24 (Mr Elhassan, Sudan); UNGOAR, Third Committee, 64th session, 39th Meeting, UN Doc A/C.3/64/SR.39 (26 January 2010) para 82 (Mr Andanje, Kenya); UN Doc A /C.3/66/SR.38 (n 57) para 75 (Mr Mahmoud, Egypt).

${ }^{122}$ UN Doc A/AC.96/SR.641 (n 76) para 62 (Ms Eltaweel, Jordan).

123 UN Doc A/C.3/64/SR.39 (n 121) para 3 (Mr Emadi, Islamic Republic of Iran).

124 See eg UNHCR Executive Committee, 66th session, Summary Record of the 687th Meeting, UN Doc A/AC.96/SR.687 (8 October 2015) para 23 (Mr Qadir Baloch, Pakistan); UN Doc A/C.3/ 70/SR.40 (n 58) para 124 (Mr Mseke, United Republic of Tanzania); UN Doc A/AC.96/SR.685 (n 76) para 63 (Mr Manicom, Canada).

${ }^{125}$ UN Doc A/AC.96/SR.689 (n 40) para 30 (Mr Zhang Lei, China). 
protecting refugees; ${ }^{126}$ take action to alleviate the burden on host countries, including through resettlement; ${ }^{127}$ uphold the principle of burden-sharing; ${ }^{128}$ recognize the fate of refugees, returnees and displaced persons as a common responsibility; ${ }^{129}$ share the burden of countries that have hosted refugees for decades: ${ }^{130}$ resolve the global problem of displacement through international burden-sharing; ${ }^{131}$ assume responsibilities to enable Jordan to continue to serve as a safe haven for refugees; ${ }^{132}$ recognize joint responsibility for refugees, returnees and displaced persons, ${ }^{133}$ share responsibility for hosting Afghan refugees in Pakistan; ${ }^{134}$ and step up efforts to assist developing countries to overcome challenges. ${ }^{135}$

Taking this even further, some States have referred explicitly to an obligation or a duty on the part of the international community to engage in burden- and responsibility-sharing. ${ }^{136}$ France claimed in 2015 that 'the unprecedented global migration crisis ... imposed an obligation on every country to take urgent action'. ${ }^{137}$ With respect to Syria, Libya stated in 2013 that the international community was 'duty-bound' to contribute sufficient funds to house, feed and care for refugees in host countries, ${ }^{138}$ and Brazil asserted that countries that did not share borders with Syria 'had a duty' to improve access to their territories by Syrian refugees. ${ }^{139}$

In 2012, Egypt asserted that Member States had 'an obligation under international law to ensure that global efforts to protect and assist refugees were successful', ${ }^{140}$ and Bangladesh argued that the international community had 'a clear obligation' to address the root causes of the presence of Muslim refugees in its territory. ${ }^{141}$ China emphasized in 2007 that UNHCR, the

126 UN Doc A /C.3/65/SR.38 (n 56) para 64 (Mr Gendi, Egypt).

127 UNGOAR, Third Committee, 63rd session, 36th Meeting, UN Doc A/C.3/63/SR.36

(4 February 2009) para 44 (Ms Blic, France, speaking on behalf of the European Union).

128 UN Doc A/AC.96/SR.668 (n 74) para 7 (Ms Mukantabana, Rwanda).

129 UNGOAR, Third Committee, 66th session, 40th Meeting, UN Doc A /C.3/66/SR.40 (13 February 2012) para 12 (Ms Khanum, Pakistan).

${ }^{130}$ UN Doc A/C.3/64/SR.39 (n 121) para 48 (Ms Sobhan, Bangladesh).

131 UN Doc A/AC.96/SR.653 (n 94) para 86 (Mr Chebih, Algeria).

132 UN Doc A/AC.96/SR.666 (n 79) para 16 (Mr Judeh, Minister for Foreign Affairs, Jordan).

133 UNGAOR, Third Committee, 67th session, 33rd Meeting, UN Doc A/C.3/67/SR.33 (27 December 2012) para 2 (Mr Tarar, Pakistan).

134 UN Doc A/C.3/64/SR.39 (n 121) para 34 (Mr Tarar, Pakistan).

135 UNGOAR, Third Committee, 63rd session, 37th Meeting, UN Doc A/C.3/63/SR.37 (13 January 2009) para 20 (Ms Mah, Thailand).

136 Note that in 1988, UNHCR's Executive Committee recognized in Executive Committee Conclusion No 52 (XXXIX) on International Solidarity and Refugee Protection (10 October 1988) para 4 that 'in all circumstances, the respect for fundamental humanitarian principles is an obligation for all members of the international community, it being understood that the principle of international solidarity is of utmost importance to the satisfactory implementation of these principles'.

137 UN Doc A/AC.96/SR.689 (n 40) para 36 (Ms Laurin, France).

138 UN Doc A/AC.96/SR.668 (n 74) para 19 (Mr Almabroug, Observer for Libya).

139 UNHCR Executive Committee, 64th session, Summary Record of the 667th Meeting, UN Doc A/AC.96/SR.667 (12 November 2013) para 39 (Mr Aldo Salone, Brazil).

140 UN Doc A/AC.3/67/SR.32 (n 49) para 67 (Mr Selim, Egypt).

141 UN Doc A/C.3/67/SR.33 (n 133) para 4 (Mr Rahman, Bangladesh). 
international community and developed countries in particular had 'a duty to help' developing host countries in a spirit of solidarity and burden-sharing. ${ }^{142}$ In 2000, the United States emphasized that it was 'the obligation of Member States to adequately fund UNHCR'. ${ }^{143}$

At first glance, these references to an obligation or a duty on the part of States appear to be framed rather strongly. However, while some States have set out clear obligations - such as providing funding, addressing root causes or improving access for refugees - others have been rather vague as to what the 'obligation' actually is. Taking urgent action at a global level, ensuring the success of global efforts and helping developing host countries, for example, are hardly solid obligations. Arguably, these States were willing to acknowledge that the international community has an 'obligation' to act, but not to take this further by spelling out its substance. The questionable practices by some of the States that have made such statements also calls into doubt their genuine commitment to the 'obligations' they promote.

Further, it is important to note that the vast majority of statements implying some level of obligation on the part of the international community-from the weaker expressions of what States 'should' do, through to the concrete statements of their alleged duties or obligations - have come from developing countries, many of which host large refugee populations. These are the States that would be most likely to benefit from greater responsibility-sharing. Developed countries, which are the primary target of such calls, have rarely commented on the nature of their obligations in this regard.

\section{B. The Basis for States' Positions}

Some commentators have developed theories and drawn conclusions about why States engage in responsibility-sharing. ${ }^{144}$ For example, Kritzman-Amir and Berman have commented that ' $[\mathrm{u}]$ nder the current international regime, all state practices that express the principle of responsibility-sharing are voluntary and considered to be a matter of "charity," not obligation'. 145 Other commentators, such as Thielemann and Betts, rationalize States' acts of responsibility-sharing according to the benefits that accrue to them, with Betts arguing that "States in "the North" do not engage in burden-sharing for purely altruistic reasons or because of an interest in refugee protection for its own sake but because of having linked interests in other issue-areas, notably

\footnotetext{
142 UNHCR Executive Committee, 58th session, Summary Record of the 613th Meeting, UN Doc A/AC.96/SR.613 (14 April 2009) para 27 (Mr La Yifan, China).

143 UN Doc S/PV.4219 (n 73) 7 (Mr Cunningham, United States of America).

144 For an overview, see P Mathew and T Harley, Refugees, Regionalism and Responsibility (Edward Elgar 2016) 100. For an analysis of States' possible motivations for burden-sharing, see Thielemann (n 29).

145 Kritzman-Amir and Berman (n 44) 633.
} 
in relation to migration, security and trade. ${ }^{146}$ Some commentators also point out that engaging in burden-sharing can serve as a type of 'insurance' against unexpected future occurrences. ${ }^{147}$

It is not possible to deduce the basis on which developed countries have engaged in responsibility-sharing solely from their statements at UN meetings over the past decade. Realistically, as mentioned above, these are not likely to be fora in which States will voluntarily assert their own commitments, let alone provide justifications for them.

Nevertheless, on several occasions developing and/or host countries have outlined, or at least alluded to, reasons why the international community should be doing more to cooperate. In 2016, for example, Egypt called on all States 'to respect the tenets of the international refugee regime' when urging States to uphold the principle of international cooperation, ${ }^{148}$ emphasizing that this principle is rooted in the international legal framework. Other States have taken more of a moral standpoint, urging the international community to 'demonstrate compassion, commitment and support', ${ }^{149}$ or emphasizing that it does not make sense for one country to shoulder so much of the refugee burden alone. ${ }^{150}$

Some States have suggested that host countries provide protection 'on behalf of the international community', ${ }^{151}$ implying that hosting refugees in itself is an act of international cooperation for which other States ought to be responsible as well. In 2007, for example, Zambia stated before the General Assembly that '[r]efugees and internally displaced persons were the responsibility of the international community and countries of asylum were carrying a burden on its behalf'. ${ }^{152}$ Similarly, in 2015, Jordan insisted that 'the world must share the burden with us, because we are performing that humanitarian duty on behalf of all humankind'. ${ }^{153}$ UNHCR appears to share this viewpoint, explaining that ' $[\mathrm{c}]$ ompliance with international refugee law represents a form of responsibility-sharing, through which States honour their

146 Betts (n 49) 11. Thielemann examined the norm-based and interest-based motivations for States agreeing to burden sharing: ER Thielemann, 'Burden Sharing: The International Politics of Refugee Protection' (The Center for Comparative Immigration Studies, Working Paper 134, 2006) $12-13$.

147 See eg Thielemann (n 29) 256; Hathaway and Neve (n 5) 145; Schuck (n 6) 249-50; cf D Anker, J Fitzpatrick and A Shacknove, 'Crisis and Cure: A Reply to Hathaway/Neve and Schuck' (1998) 11 HarvHumRtsJ 295.

${ }_{148}$ UN Doc A/C.3/70/SR.40 (n 58) para 98 (Mr Moussa, Egypt).

149 ibid para 123 (Mr Hassani Nejad Pirkouhi, Islamic Republic of Iran).

150 Iran stated simply that '[i]t did not make sense for one country to receive nearly 10 per cent of the world's refugees while other countries felt no responsibility to shoulder the burden': UN Doc A/ C.3/63/SR.37 (n 135) para 18 (Mr Emadi, Islamic Republic of Iran). Similarly, Kenya noted that it was 'shouldering a far larger burden that it could or should bear': UN Doc A/C.3/66/SR.38 (n 57) para 21 (Mr Kimani, Kenya).

${ }_{151}$ UN Doc A/C.3/70/SR.40 (n 58) para 99 (Mr Moussa, Egypt).

152 UN Doc A/C.3/62/SR.41 (n 69) para 25 (Mr Kapambwe, Zambia).

153 UN Doc S/PV.7588 (n 79) 7 (Mr Judeh, Jordan). 
commitments to each other, as expressed in the 1951 Convention and other refugee law instruments'. ${ }^{154}$

In 2015, Armenia brought another dimension to the issue by stating that 'the international community must intervene when Governments [are] unwilling or unable to provide the necessary aid'. ${ }^{155}$ This raises an interesting question as to when the international community is expected to provide support and assistance to host countries. Should this extend, as Armenia suggests, to situations where a country is unwilling to provide assistance? Would this principle only apply to developing countries?

\section{V. 'COMMON BUT DIFFERENTIATED RESPONSIBILITIES': AN EMERGING CONCEPT IN} REFUGEE LAW?

Perhaps the most complex question with respect to responsibility-sharing is how States' responsibilities should be measured. As discussed above, responsibility-sharing is a collective undertaking which depends upon, but does not define, the individual contributions of States. It is against this background that the principle of common but differentiated responsibilities has been considered in the context of refugee law, mostly by commentators but also more recently by States and UNHCR, as discussed below. This principle recognizes that States have different strengths and capacities to protect refugees, and that it is not reasonable or realistic to expect all States to contribute in the same way and to an equal degree.

The principle of common but differentiated responsibilities, derived from international environmental law, has been a key aspect of many of the burden-sharing proposals made by commentators over the years. ${ }^{156}$ Schuck explains that it is 'both a norm of fairness and a constraint dictated by political prudence', noting that it is 'probably essential to both consent and broad participation'. ${ }^{157}$ According to Hathaway and Neve, '[u]nder a system of common but differentiated responsibility, the net resources available for refugee protection would be maximized by calling on states to contribute in ways that correspond to their relative capacities and strengths'. ${ }^{158}$ Hathaway has since described it as

154 Note on International Protection (n 7) para 10.

155 UN Doc A/C.3/69/SR.41 (n 83) para 89 (Mr Sargsyan, Armenia). An interesting parallel can be found in the International Law Commission's Draft Articles on the Protection of Persons in the event of Disasters (2016) art 11(1): 'To the extent that a disaster manifestly exceeds its national response capacity, the affected State has the duty to seek assistance from, as appropriate, other States, the United Nations, and other potential assisting actors.' While the provision of external assistance requires an affected State's consent, affected States must not withhold such consent arbitrarily (art 13). See also Implementing the Responsibility to Protect: Report of the SecretaryGeneral, UN Doc A/63/677 (12 January 2009).

156 See eg Hathaway and Neve (n 5) 117-18; Schuck (n 6) 271; Kritzman-Amir (n 6) 375-6; MR Alborzi, Evaluating the Effectiveness of International Refugee Law: The Protection of Iraqi Refugees (Martinus Nijhoff 2006) 245; Wall (n 6).

158 Hathaway and Neve (n 5) 210-11. 
meaning that beyond the common duty to provide first asylum, states could assume a range of protection roles within their responsibility-sharing quota (protection for duration of risk; exceptional immediate permanent integration; residual resettlement) - though all states would be required to make contributions to both (financial) burden-sharing and (human) responsibilitysharing, with no trade-offs between the two. ${ }^{159}$

Participants at a UNHCR-facilitated meeting of experts in 2011 also recognized that providing for differentiated contributions by States in cooperative arrangements, based on needs and capacities, could be 'a good way to incentivise cooperation and create political momentum'. ${ }^{160}$ In 2014, emphasizing the need for a global pact of solidarity, the UN High Commissioner for Refugees himself advised the General Assembly that this should be 'based on burden-sharing and common but differentiated responsibilities'. 161

The principle of common but differentiated responsibilities is central to international environmental law, ${ }^{162}$ and is reflected, for instance, in the United Nations Framework Convention on Climate Change. ${ }^{163}$ The principle recognizes that States have contributed to environmental problems to differing degrees and have varying capacities to address them. ${ }^{164}$ In the refugee law context, the principle focuses predominantly on the latter consideration: namely, that the protection of refugees is the responsibility of all States, irrespective of whether they have contributed to the causes of displacement, and each can contribute to protection in different ways. According to Wall, 'the apportionment of blame for refugee flows is neither necessary nor appropriate in the refugee context', although he does recognize that developed countries have 'special responsibilities' owing to their greater capacities. $^{165}$

159 JC Hathaway, 'A Global Solution to a Global Refugee Crisis' (Open Democracy, 29 February 2016) <https://www.opendemocracy.net/openglobalrights/james-c-hathaway/global-solution-toglobal-refugee-crisis $>$.

160 UNHCR Expert Meeting (n 26) 3.

${ }^{161}$ UNGAOR, Third Committee, 68th session, 41st Meeting, UN Doc A/C.3/68/SR.41 (6 November 2013) para 12 (Mr Guterres, UN High Commissioner for Refugees).

162 For a discussion of this principle in the context of States' responsibilities to assist people who are forced to leave their territory as a result of the unavoidable effects of climate change, see $\mathrm{R}$ Eckersley, 'The Common but Differentiated Responsibilities of States to Assist and Receive "Climate Refugees"' (2015) 14 European Journal of Political Theory 481.

163 United Nations Framework Convention on Climate Change (adopted 9 May 1992, entered into force 21 March 1993) 1771 UNTS 107. The Preamble states that 'the global nature of climate change calls for the widest possible cooperation by all countries and their participation in an effective and appropriate international response'. The principles of 'equity' and 'common but differentiated responsibilities and respective capabilities' apply: see arts 3(1), 4(1).

164 Hathaway and Neve (n 5) 144-5 (fns omitted); Wall (n 6). See also 'The Principle of Common But Differentiated Responsibilities: Origins and Scope: A CISDL Legal Brief' (2002)<http://cisdl. $\mathrm{org} /$ public/docs/news/brief_common.pdf>, which explains further that '[a]s developed countries have played the greatest role in creating most global environmental problems, and have superior ability to address them, they are expected to take the lead on environmental problems'.

165 Wall (n 6) fn 147. 
Nevertheless, a number of commentators do call for countries of origin to accept some degree of responsibility for their involvement in causing the displacement of refugees. ${ }^{166}$ Schuck points out that some States are likely to reject a voluntary obligation to share responsibility for refugees if they did not generate their displacement and are unlikely to receive refugees themselves. ${ }^{167}$ Focusing on addressing the causes, rather than attributing responsibility for them, Suhrke has commented that 'States would have more incentives to accept responsibility-sharing schemes if they simultaneously had some assurance that they could control events that produce refugees.' 168

While this article does not advocate attributing responsibilities to States on a causal basis, ${ }^{169}$ it does acknowledge the difficulty of encouraging States to engage in responsibility-sharing on purely humanitarian grounds. ${ }^{170}$ Further, if States are left to assess their own capacity to contribute to responsibilitysharing subjectively, pursuant to the principle of common but differentiated responsibilities, this is likely to limit its effectiveness. ${ }^{171}$ Having said this, States are unlikely to have it any other way.

States have not explicitly discussed the principle of common but differentiated responsibilities in the refugee context in their statements to the UN. However, as noted above, developing countries have sometimes called on developed or 'rich' countries to step up their efforts to share the 'burden', implying that they have greater responsibilities on account of their wealth. ${ }^{172}$ The concept of common but differentiated responsibilities was also indirectly raised at the UN Summit in New York, during a roundtable discussion on a compact for responsibility-sharing for refugees. The Deputy Foreign Minister of Estonia stated, for instance, that ' $[\mathrm{w}] \mathrm{e}$ all have to contribute in a spirit of burden-sharing and using different policies and means available in order to

166 See JI Garvey, 'Toward a Reformulation of International Refugee Law' (1985) 26 HarvIntlLJ 483, 496-7; Koser (n 5) 6; Kritzman-Amir (n 6) 375-6; Kritzman-Amir and Berman (n 44) 628. This point has also been noted by Schuck (n 6) 249.

167 He does, however, point out that States might be willing to engage in small-scale burdensharing as a form of insurance against future events: Schuck (n 6) 249.

168 Suhrke (n 23) 399-402.

169 This has been proposed in the context of climate change-related displacement as well: see eg S Byravan and S Chella Rajan, 'Providing New Homes for Climate Change Exiles' (2006) 6 Climate Policy 247.

${ }^{170}$ We do not explore the idea of incentives and responsibility-sharing here, but see eg A Betts, Protection by Persuasion: International Cooperation in the Refugee Regime (Cornell University Press 2009); J Blocher and M Gulati, 'Competing for Refugees: A Market-Based Solution to a Humanitarian Crisis' (2016) 48 ColumHumRtsLRev 53; Ti Achiume (n 5); JF-H Moraga and H Rapoport, 'Tradable Immigration Quotas' (2014) 115 Journal of Public Economics 94; SD Roper and LA Barria, 'Burden Sharing in the Funding of the UNHCR: Refugee Protection as an Impure Public Good' (2010) 54 Journal of Conflict Resolution 616; J McAuley, 'Refugee Crisis: Central Europe Told Settle Migrants or Pay $\$ 385,000$ Fine per Person' Sydney Morning Herald (5 May 2006) < http://www.smh.com.au/world/migrant-crisis/refugee-crisis-central-europe-told-settlemigrants-or-pay-385000-fine-per-person-20160504-gomli2.html>.

171 For a discussion of the 'discretion attached to humanitarianism' in the context of climate change-related displacement, see Eckersley (n 162) 488-9.

${ }^{172}$ UN Doc A/C.3/64/SR.39 (n 121) para 76 (Mr Nofukuka, South Africa). 
find a solution for this common concern of global scale'. ${ }^{173}$ Focusing specifically on host countries, the Director General of the Bureau of Foreign and Immigrant Affairs of the Republic of Iran stated that any new commitments on the part of host countries 'should be in conformity with their national capacities and legislations'. ${ }^{174}$

The New York Declaration contains a version of the common but differentiated responsibilities principle, although it is not articulated as such. Paragraph 68 provides that: States commit 'to a more equitable sharing of the burden and responsibility for hosting and supporting the world's refugees, while taking account of existing contributions and the different capacities and resources among States'. ${ }^{175}$ While this is a step forward, it is unlikely to change the current situation without further clarification as to the precise nature of States' differing responsibilities. For example, how will it be decided (and by whom) whether a State should provide financial assistance, pathways for refugees, or both? What level of assistance will States provide, and how will this be determined? Which States will be responsible for sharing the burden for which displacement situations? Will hosting refugees in itself be considered as an act of responsibility-sharing?

Commentators have made a number of suggestions about how a better allocation of responsibilities could be achieved. For instance, Fonteyne has argued that each State should participate in financing refugee programmes and providing resettlement opportunities 'to the full extent of its capabilities'. ${ }^{176}$ Hathaway and Neve have developed a list of indicators to measure what would be fair in the context of their proposed burden-sharing mechanism. ${ }^{177}$ Chimni has proposed adjusting States' refugee intake based on land mass and population density. ${ }^{178}$ Kritzman-Amir argues that 'wealthier countries with stronger absorption abilities should bear more responsibility than poorer countries', and that States with a 'specific bond of solidarity' with countries of origin should bear greater responsibility than those that do not. ${ }^{179}$

\footnotetext{
173 Statement by Deputy Foreign Minister of Estonia, Mr Väino Reinart, Round Table 4 (n 54) 1.

174 Statement by Mr Mohammadi Far, Director General of the Bureau of Foreign and Immigrant Affairs, Ministry of Interior of the Islamic Republic of Iran, Round Table 4 (n 54) 2.

175 New York Declaration (n 1) para 68 (emphasis added). See also Zero Draft of a Global Compact (n 9) para 12. $\quad{ }^{176}$ Fonteyne (n 28) $187 . \quad{ }_{177}$ Hathaway and Neve (n 5) 202ff. ${ }^{178}$ BS Chimni, 'The Operational Mechanism: International Burden Sharing, in Reconceiving Refugee Law as Human Rights Protection' (Background Paper for the Meeting of the Legal Working Group) 86, 104-7 (April 1993) (unpublished manuscript), cited in Hathaway and Neve (n 5) 204. Grahl-Madsen earlier suggested that refugee quotas should be based on GNP and population size: A Grahl-Madsen, 'Refugees and Refugee Law in a World of Transition' [1982] Michigan Yearbook of International Legal Studies 65, 74, cited in Hathaway and Neve (n 5) 203.

179 Kritzman-Amir (n 6) 375-6. In the climate change context, Eckersley (n 162) 484 identifies 'the most mooted ethical principles for fleshing out the meaning of [the common but differentiated responsibilities principle]' to be the polluter pays principle, the beneficiary pays principle and the ability to pay principle.
} 
Realistically, it would be easier to define the specific responsibilities of States in the context of a particular displacement situation, rather than in the abstract. This could be facilitated by the new Comprehensive Refugee Response Framework, annexed to the New York Declaration, which is 'based on the principles of international cooperation and on burden- and responsibilitysharing' ${ }^{\prime 80}$ and sets out the relevant elements in responding to situations of large-scale refugee movement. These include ensuring: (a) 'adequate, safe and dignified' facilities for the reception and admission of refugees; ${ }^{181}$ (b) support for immediate and on-going needs, including adequate financial and other resources, development funding mechanisms, and empowering refugees to establish supportive systems and networks; ${ }^{182}$ (c) support for host countries and communities, including through a joint, impartial and rapid risk and/or impact assessment to identify and prioritize assistance and needs; ${ }^{183}$ and (d) securing durable solutions, ${ }^{184}$ the success of which 'depends in large measure on resolute and sustained international cooperation and support'. ${ }^{185}$ The document stresses throughout the importance of partnerships between States, international organizations, financial institutions, multilateral donors, civil society, refugees and the private sector, as well as closer cooperation and joint planning between humanitarian and development actors. ${ }^{186}$

Having surveyed a wide range of past cooperative arrangements, Türk and Garlick argue that the following features have been integral to their success: (a) recognition of the value of common interests among concerned States; (b) commitments by States in different geographical areas to contribute; (c) a focus on the development of region- or situation-specific strategies; (d) acknowledgment that refugee movements often form part of 'mixed' migration movements; and (e) willingness to engage in on-going follow-up processes. ${ }^{187}$

\footnotetext{
${ }^{180}$ Comprehensive Refugee Response Framework, Annex 1 to the New York Declaration (n 1) para 1.

${ }_{181}$ ibid para 5. Note that this does not include reference to those who are not refugees but are in need of protection, as included in the Zero Draft of a Global Compact (n 9) para 13.

182 Comprehensive Refugee Response Framework, Annex 1 to the New York Declaration (n 1) paras 6-7.

183 ibid para 8 .

184 ibid paras 9-14. Note that the provisions on resettlement are much weaker than those that were included in the Zero Draft of a Global Compact. For example, the provision in the Zero Draft that called upon States to '[m]ake available or enhance or facilitate admission pathways for refugees' has been softened, calling upon third countries to '[c]onsider making available or expanding ... resettlement opportunities and complementary pathways for admission of refugees'. Similarly, a provision calling on States to '[a]pply more flexible criteria for resettlement and humanitarian admission programmes' has been weakened to '[c]onsider broadening the criteria'. Compare Zero Draft of a Global Compact (n 9) para 21 with New York Declaration (n 1) paras 14(a), 14(b).

${ }^{185}$ Comprehensive Refugee Response Framework, Annex 1 to the New York Declaration (n 1) para 9. See para 14 for more information about what this includes.

${ }^{186}$ See eg New York Declaration (n 1) paras 38, 85.

187 Türk and Garlick (n 20) 672-3. For an excellent overview of past burden-sharing arrangements, see 665-73.
} 
Since the Comprehensive Refugee Response Framework will form the basis of the 2018 Global Compact on Refugees, ${ }^{188}$ these ideas about the content of responsibility-sharing may begin to shape the future cooperative underpinnings of the international protection regime. As Türk and Garlick make plain, enhanced international cooperation can help to ensure 'more effective, swift, and comprehensive responses to the needs of refugees', ${ }^{189}$ while '[p]redictability and equity are also intrinsic features of any functioning international cooperative framework'. ${ }^{190}$ While they argue that an additional Protocol to the 1951 Convention would be the best way to entrench such a response in the longer term, ${ }^{191}$ an incremental approach seems more realistic.

\section{CONCLUSION}

The UN Special Representative of the Secretary-General for International Migration, Peter Sutherland, has stated that 'refugees are the responsibility of the world. ...Proximity doesn't define responsibility.' ${ }^{192}$ Yet, as this article has shown, the international community still has a long way to go before equitable responsibility-sharing becomes a reality. States do not share the same understanding of, or level of commitment towards, this key principle of international refugee law. In the UN meetings examined, the majority of calls for greater responsibility-sharing have come from developing States, particularly host countries. Though some developed States have acknowledged the need for greater responsibility-sharing, they have been reluctant to recognize any concrete obligations on their part.

By examining what States have said in UN fora over the past decade, this article has shown (perhaps unsurprisingly) that those States with the greatest capacity to protect refugees tend to have the least political will to do so. This may, in the end, be counterproductive: as Goodwin-Gill and McAdam have noted, '[n]ational self-interest may prevail when States are confronted with population displacements on their borders, but national goals will often be best achieved through cooperation with others'. ${ }^{193}$

The statements examined for this research were made over the course of the last decade, and admittedly some progress has been made during that period. States have called for a strengthening of the responsibility-sharing regime in their various statements, particularly in recent years. For example, at the Security Council in 2000, the representative for Bangladesh explained that

\footnotetext{
188 Comprehensive Refugee Response Framework, Annex 1 to the New York Declaration (n 1) para 19. For a detailed analysis of the ways in which this could enhance international cooperation, see Türk (n 7) 45; Türk and Garlick (n 20) 674-8. 189 Türk and Garlick (n 20) 657.

190 Turk and Garlick (n 20) $658 . \quad 191$ ibid 673, 678.

192 'Refugees Are the Responsibility of the World ... Proximity Doesn't Define Responsibility', UN News Centre, Interview with Peter Sutherland (2 October 2015) <http://www.un.org/apps/ news/story.asp?NewsID=52126\#.WVSLOYSGPA4>.

193 Goodwin-Gill and McAdam (n 47) 505.
} 
'[m]y delegation strongly believes in reaching an international consensus on the need for burden-sharing with countries hosting refugee populations'. ${ }^{194}$ More recently, in 2012, Kenya stated that ' $[\mathrm{t}]$ he international community and the United Nations must urgently explore new options to build a more equitable international burden-sharing regime'. 195

Also in 2012, Tunisia commented that ' $[\mathrm{t}]$ he values of solidarity and cooperation should be better defined and incorporated into the relevant international instruments so as to promote global solidarity and greater involvement on the part of developed countries'. ${ }^{196}$ The following year, in relation to the Syria crisis, Pakistan noted that 'the question of burdensharing required new and innovative approaches, and that the issue should no longer be brought up intermittently but should rather form an integral part of UNHCR plans and policies'. ${ }^{197}$ In 2016, Egypt referred to the need 'to reinvigorate the initiative to complement the 1951 Convention and 1967 Protocol to realize a more equitable partnership in sharing burdens and responsibilities'. 198

Yet, as discussed throughout this article, the 2016 New York Declarationthe most recent articulation of the international community's willingness to engage in responsibility-sharing - has fundamental weaknesses. Significantly, despite its commitment to a more equitable sharing of the burden and responsibility for hosting and supporting refugees, ${ }^{199}$ it contains no concrete commitments to provide financial assistance to host countries or to increase the provision of resettlement places and other admission pathways. ${ }^{200}$ What this overarching commitment to more equitable burden- and responsibilitysharing means in practice, therefore, remains to be seen.

The unfortunate reality is that States appear unwilling to open up additional pathways to refugees on a large scale. At the Leaders' Summit in New York on 20 September 2016, States' pledges to roughly double the number of resettlement places or other legal admission channels to refugees that year were criticized as insufficient. For example, the Secretary-General of Amnesty International commented that '[w]ealthy countries cannot only

194 UN Doc S/PV.4219 (n 73) 15 (Mr Ahmed, Bangladesh).

195 UN Doc A/AC.3/67/SR.32 (n 49) para 71 (Mr Maina, Kenya).

196 UN Doc A/AC.96/SR.648 (n 64) para 27 (Mr Mebazaa, President ad interim of the Republic of Tunisia).

197 UN Doc A/AC.96/SR.667 (n 139) para 11 (Mr Baloch, Pakistan).

198 UN Doc A/C.3/70/SR.40 (n 58) para 99 (Mr Moussa, Egypt).

199 New York Declaration (n 1) para 68.

200 In the Declaration, States note that they 'intend' to expand the number and range of legal pathways available to refugees, 'urge' States that do not have resettlement programmes to establish them and encourage others to expand them, and will 'consider' expanding complementary admission pathways: ibid paras 77, 78, 79. The Declaration notes that States 'aim' to meet UNHCR's annual resettlement needs through resettlement and other legal pathways (para 78). Similar provisions are reflected in the Comprehensive Refugee Response Framework, paras 14, 15, 16. 
commit money and walk away. The 360,000 resettlement places offered globally need to be seen in the context of more than 20 million refugees worldwide.' 201 Furthermore, a provision in an earlier draft of the New York Declaration that called on States to resettle 10 per cent of the global refugee population annually was removed. ${ }^{202}$

States - especially developed ones — seem much more willing to provide financial assistance than to accept refugees into their territories. But this is not enough: physical protection is an essential component of responsibilitysharing. Further, although financial assistance is essential, there is a risk that this can be used by States in a counterproductive way. As Brazil noted in a discussion at the 2016 UN Summit, '[w]e must be cautious regarding the possibility that the provision of financial support to humanitarian agencies or refugee-hosting countries could serve, in some cases, to compensate for the adoption of policies that restrict the entrance of asylum seekers' ${ }^{203}$

Overall, States are clearly not ready to undertake concrete commitments for responsibility-sharing in the form of a new international instrument, even if it is non-binding. ${ }^{204}$ While the 2018 Global Compact on Refugees has the potential to better define States' responsibilities in this context, expectations should not be set too high. If States are not willing to undertake clear commitments now, this is unlikely to change dramatically in the course of the next year, especially given the absence of a solid legal or causal basis on which to base such responsibilities. If the principle of common but differentiated responsibilities is to be implemented in practice, then the international community must focus on defining how it will operate. Otherwise, there is a risk that it will be used by States not to expand their commitments, but simply to justify the status quo.

\footnotetext{
201 'Refugee Crisis: "Leaders' Summit" Fails to Show Leadership on Refugees', Amnesty International News (online) (21 September 2016) < https://www.amnesty.org/en/latest/news/2016/ 09/refugee-crisis-leaders-summit-fails-to-show-leadership/>.

202 Michael Astor, 'World Leaders at UN Approve Plan for Refugee Crisis', New Europe (online) (19 September 2016) < https://www.neweurope.eu/article/world-leaders-un-approve-plan-refugeecrisis/>. See Zero Draft of a Global Compact (n 9) para 23: 'Member States will work towards the provision of resettlement places and other legal pathways on a scale which would enable at least 10 per cent of the global refugee population to benefit annually.'

203 Statement by HE Alexandre de Moraes, Minister of Justice and Citizenship of Brazil, Round Table 4 (n 54) 2.

204 According to Gottwald (n 29) 526, Western States 'are not yet prepared to translate their verbal commitment to responsibility sharing into normative frameworks on international burden sharing'.
} 